\title{
ASUPAN ZAT GIZI DAN STATUS GIZI REMAJA PUTRI DI PONDOK PESANTREN FIRDAUS
}

\author{
Zulia Setiyaningrum*1 \\ ${ }^{1}$ Program Studi Ilmu Gizi, Fakultas Ilmu Kesehatan, Universitas Muhammadiyah Surakarta, Indonesia \\ *e-mail: ${ }^{1}$ zs399@ums.ac.id
}

\begin{abstract}
ABSTRAK
Pertumbuhan serta perkembangan tubuh pada remaja memerlukan energi dan zat gizi yang lebih banyak. Pertumbuhan dan perkembangan jika tidak diimbangi dengan asupan zat gizi yang seimbang akan mengakibatkan masalah gizi, baik defisiensi akan zat gizi maupun obesitas. Kabupaten Jembrana memberikan kontribusi terhadap angka masalah gizi pada anak remaja di Provinsi Bali. Tujuan penelitian yaitu menganalisis hubungan asupan energy, karbohidrat, protein dan lemak dengan status gizi pada remaja putri di Pondok Pesantren Firdaus. Penelitian cross-sectional ini melibatkan 52 remaja putri dengan usia 12-17 tahun yang dipilih dengan menggunakan sistematic random sampling. Data asupan zat gizi diambil dengan waawancara menggunakan form food recall 24 jam selama 3 hari, data status gizi berdasarkan IMT/U diperoleh dengan pengukuran berat badan menggunakan tmbangan digital dan pengukuran tinggi badan menggunakan microtoise. Data dianalisis dengan software SPSS, uji kenormalan menggunakan uji Komogorov Smirnov dan uji hubungan dengan uji Person Product Moment. Hasil penelitian ini menunjukkan asupan energi, protein, lemak dan karbohidrat subjek rata-rata defisiensi berat, status gizi subjeksebagian besar termasuk gizi baik (67,3\%). Uji hubungan asupan energi, protein dan karbohidrat dengan status gizi mendapatkan hasil nilai p berturut-turut $(0,26 ; 0,38 ; 0,84)$, uji hubungan asupan lemak dengan status gizi mendapatkan hasil nilai p $(0,03)$. Kesimpulan yang didapat adalah terdapat hubungan asupan lemak dengan status gizi, tidak terdapat hubungan asupan energi, protein, karbohidrat dengan status gizi.
\end{abstract}

Kata kunci: Asupan energi, Asupan karbohidrat, Asupan lemak, Asupan protein, Status gizi

\begin{abstract}
The growth and development of the body in adolescents requires more energy and nutrients. Growth and development that is not balanced with a balanced intake of nutrients can lead to nutritional problems, both nutritional deficiency and obesity. Jembrana Regency contributes to the number of nutritional problems in adolescents in Bali Province. This study aims to analyze the relationship between energy, carbohydrate, protein and fat intake with nutritional status in adolescent girls at Firdaus Islamic Boarding School. This cross-sectional study involved 52 young women aged 12-17 years who were selected using systematic random sampling. Nutrient intake data were taken by interview using a 24-hour food recall form for 3 days, nutritional status data based on BMI/U were obtained by measuring weight using digital scales and measuring height using microtoise. Data were analyzed using SPSS software, normality test using Kolmogorov Smirnov test and relationship test using Pearson Product Moment test. The results of this study showed that the average intake of energy, protein, fat and carbohydrates of the subjects was severe deficiency, the nutritional status of most of the subjects included good nutrition (67.3\%). The test of the relationship of energy, protein and carbohydrate intake with nutritional status got p-value results $(0.26$; $0.38 ; 0.84)$, the test of the relationship between fat intake and nutritional status got p-value (0.03). The conclusion obtained is that there is a relationship between fat intake and nutritional status, there is no relationship between energy, protein, carbohydrate intake with nutritional status.
\end{abstract}

Keywords: Energy intake, Carbohidrate intake, Fat iintake, Protein iintake, Nutritional status

\section{PENDAHULUAN}

Pada masa remaja terjadi perubahan fisik, perubahan bentuk tubuh serta masa menstruasi [1]. Perkembangan pada identitas pribadi, sistem nilai moral, persepsi body image, harga diri serta masalah psikososial juga terjadi saat remaja [2].Remaja merupakan keelompok yang rentan terhadap berbagai masalah gizi sepertii gizi kuurang atau gizi lebih [3]. Perceeepatan 
pertumbuhan dan perkmbangan tubuh pada remaja membutuhkan energi dn zat gizi yang lebih banyak. Pertumbuhan dan perkembangan yang tidak dimbangi dengan asupan zat gizi yang sembang dapat menyebabkan masalah gizi, baik defisiensi zat gizi maupun obesitas [4,5].

Data Riskesdas tahun 2013 dan tahun 2018 menyebutkan bahwa Provinsi Bali termasuk ke dalam Provinsi yang memiliki anak usia 5-12 thun dan remaaja usia 13-15 tahun dengan prevalensi gemuk dan sagat gemuk di atas Nasional, serta terjadi kenaikan prevalensi gizi gemuk dan sangat gemuk pada anak usia 5-12 tahun yaitu sebanyak 2,2\% dan 7,9\% pada remaja usia 1315 tahun [6,7]. Laporan Riskesdas tahun 2018 menunjukkan Kabupaten Jembrana memberikan kontribusi terhadap angka masalah gizi pada anak remaja di Provinsi Bali, yaitu pada anak usia 5-12 tahun dengan persentase sangat kurus dan kurus sebesar 8,69\% dan persentase status gizi gemuk dn sangat gemuk sebesar 16,38\%, sedangkan pada remaja usia 13-15 tahun dengan persentase kurus sebesar 2,97\% dan persentase sttus gizi gemuk dan sagat gemuk sebesar 15,92\% [8].

Penelitian tentang asupan zat gizi dan status gizi pada remaja puti di SMK Ciawi Bogor, menjelaskan bahwa terdapat hubugan yang sigifikan antara asupan enerrgi, protein, dan karbohidrat degan status gizi [9]. Hasil penelitian tingkat keckupan energi dan zat gizi makro dengan status gizi pada siswi SMA Pondok Psantren Al-Izah Kota Baru menunjukkan ada hubungan yang signifikan, dengan rata-rata responden memiliki tingkat kecukupan energi dan zat gizi makro termasuk ke dalam kategori inadekuat dan status gizi normal [10].

Penelitian pendahuluan pada 65 remaja putri Pondok Putri Firdaus mendapatkan hasil sebanyak 29,2\% termasuk kategori status gizi lebih, dan 1,53\% termasuk kategori status gizi kurang. Dari hasil pengamatan remaja putri lebih memilih mengonsumsi makanan yang disenangi, jika mnu yang disajikan oleh petugas dapur tidak sesuai dengan selera maka biasanya mereka akan memilih mengonsumsi snack, mie instan atau hanya di ambil nasi dan ditambah dengan lauk yang dibawakan dari rumah seperti abon, keripik dan makanan lainnya. Berdasarkan pemaparan di atas, maka tujuan penelitian adalah menganalisis hubungan asupaan energi, protein, lemak dan karbohidrat dngan status gzi remaja putri di Pondok Pesantren Firdaus.

\section{BAHAN DAN METODE}

Penelitian ini mnggunakan desain crosssectional yang dilakukan pada bulan November 2020. Penelitian dilakukan di Pondok Pesantren Firdaus Jembrana, Bali. Populasi berjumlah 118 remaja putri, dan dihitung sesuai perhitungan sampel maka subjek yang diambil 52 remaja putri. Subjek dipilih dengan systematic random sampling, dengan kriteria inklusi berusia 12-17 tahun yang dipilih dengan menggunakan. Data yang diambil meliputi identitas subjek, usia, aspan energi, prtein, lemak dan karbohidrat serta status gizi. Data asupan zat gizi diambil dengan wawacara menggunakan form food recall 24 jam selama 3 hari, hasil food recall 24 jam yang didapat dihitung dengan software Nutrisurvey kemudian dibandingkan dengan AKG tahun 2019 dalam satuan gram. Data status gizi berdasarkan IMT/U didapatkan dengan cara mengukur berat badan menggunakan timbangan digital dengan ketlitian $0,1 \mathrm{~kg}$ serta pengukuran tinggi badan menggunakan micotoise dengan ketelitian $0,1 \mathrm{~cm}$, data tersebut kemudian dikonversikan menjadi Indeks Masa Tubuh. Data dianalisis dengan software SPSS, uji kenormalan menggunakan uji Kolmogrov Smirnov dan uji hubungan dengan uji Parson Product Moment.

\section{Karakteristik Responden}

\section{HASIL DAN PEMBAHASA}

Responden peneltian ini berjumlah 52 responden yaitu remaja putri di Pondok Pesantren Firdaus. Berdasarkan sifat serta ciri perkembangannya, maasa remaja memiliki tiga tahap, yaitu: masa awal remaja(10-12 tahun), masa remajaa tengah (13-15 tahun), dan masa remaaja akhir (16-19 tahun) [11].

Tabel 1 menunjukkan bahwa rentang usia responden yaitu 10 sampai 17 tahun, dan ratarata usia responden yaitu 13-15 tahun sebanyak 29 siswa $(53,84 \%)$. Remaja putri di Pondok Pesantren Firdaus termasuk remaja awal, menengah dan akhir karena memiliki rentang usia 1017 tahun, dimana remaja ini banyak mengalami perubahan, diantaranya pertambahan jaringan

JIGK Vol. 3, No. 01, Agustus 2021: $01-08$ 
lemak tubuh, massa otot serta perubahan hormon. Hal tersebut menjadi pemicu timbulnya perilaku berisiko terhadap kesehatan, sehingga dapat mengakibatkan masalah gizi pada remaja tersebut [12].

Tabel 1. Karakteristik Usia Responden

\begin{tabular}{ccc}
\hline Usia (tahun) & Frekuensi & Persentase $(\%)$ \\
\hline $10-12$ & 9 & 17,3 \\
$13-15$ & 29 & 53,84 \\
$16-17$ & 14 & 26 \\
\hline Total & 52 & 100 \\
\hline
\end{tabular}

\section{Deskripsi Asupan Zat Gizi Makro dan Status Gizi}

Asupan zat giizi makro dianalisis berdasarkan perhitungan hasil recal 3x24 jam dibandingkan dengan Angka Kecukupan Gizi masing-masing remaja putri. Kategori asupan energi meliputi kelebihan $(\geq 120 \%)$, cukup $(90-119 \%)$, defiisit ringaan $(80-89 \%)$, defisait seedang $(70-79 \%)$, defisit beraat $(<70 \%)[13]$.

Tabel 2.Deskripsi Asupan Energi

\begin{tabular}{ccc}
\hline Asupan Energi & Frekuensi & Persentase (\%) \\
\hline Defsiensi Berat & 43 & 82,69 \\
Defisiensi Sedng & 6 & 11,54 \\
Defisensi Ringan & 2 & 3,84 \\
Cukup & 1 & 1,92 \\
Kelebihan & 0 & 0 \\
\hline Asupan Protein & Frekuensi & Persentase (\%) \\
\hline Dfisiensi Berat & 44 & 84,61 \\
Defisiensi Sedag & 2 & 3,84 \\
Deisiensi Ringan & 2 & 3,84 \\
Cukup & 4 & 7,69 \\
Kelebihan & 0 & 0 \\
\hline Asupan Lemak & Frekuensi & Persentase (\%) \\
\hline Defisiensi Berat & 27 & 51,92 \\
Defisiensi Sedang & 6 & 11,53 \\
Defisiensi Ringan & 3 & 5,76 \\
Cukup & 11 & 21,15 \\
Kelebihan & 5 & 9,61 \\
\hline Asupan Karbohidrat & Frekuensi & Persentase (\%) \\
\hline Defisiensi Berat & 49 & 94,23 \\
Defisiensi Sedang & 3 & 5,76 \\
Defisiensi Ringan & 0 & 0 \\
Cukup & 0 & 0 \\
Kelebihan & 0 & 0 \\
\hline & &
\end{tabular}

Tabel 2 menunjukkan bahwa sebagian besaar responden memiliki asupan energy, protein, lemak dan karbohidrat dengan kategori defisit berat yaitu sebesar 82,69\%, 84,61\%, 51,92\% dan $94,23 \%$.

\section{Deskripsi Status Gizi}

Klasifikasi status gizi remaja putri berdasarkan perhitungan z-score IMT/U yaitu kategori gizi kurang (-3 SD sd < -2 SD), gizi baaik (-2 SD sd +1 SD), gii lebih (+1 SD sd +2 SD), obaesitas (> +2 SD)[14]. Tabel 3 menuunjukkan bahwa sebaagian besar responden memiliki status gizi baik yaitu sebesar $67,3 \%$. Persentase status gizi lebih $17,3 \%$, staus gizi obesitas $13,46 \%$ dan status gizi kurang sebesar $1,93 \%$. Hal ini sejalan dengan penelitian yang dilakukan oleh aulia 2021 mengenai status gizi siswa kelas IX SMP 02 banjarharjo lebih dari 50\% bersetatus gizi baik [15].

JIGK Vol. 3, No. 01, Agustus 2021: $01-08$ 
Tabel 3.Deskripsi Status Gizi

\begin{tabular}{ccc}
\hline Status Gizi & Frekuensi & Persentase (\%) \\
\hline Gizi Kurang & 1 & 1,92 \\
Gizi Baik & 35 & 67,3 \\
Gizi Lebih & 9 & 17,3 \\
Obesitas & 7 & 13,46 \\
\hline Total & 52 & 100 \\
\hline
\end{tabular}

\section{Hubungan Asupan Energi dengan Status Gizi}

Ketidakseimbangan antaara asupan energi, lemak, protein dan karbohidrat dengan kebutuhan gizi akan mempengaruhi status gizi remaja. Asupan energy diperoleh dari asupan makan sehari ditambah dengan jajanan di kantin sekolah maupun di luar sekolah. Berikut merupakan distribusi asupan energi dengan status gizi pada remaja putri :

Tabel 4.Distribusi Asupan Energi dengan Status Gizi

\begin{tabular}{|c|c|c|c|c|c|c|c|c|c|c|}
\hline \multirow{2}{*}{$\begin{array}{c}\text { Asupan } \\
\text { Energi }\end{array}$} & \multicolumn{8}{|c|}{ Status Gizi } & \multirow{2}{*}{ Jumlah } & \multirow{2}{*}{$\%$} \\
\hline & Baik & $\%$ & Kurang & $\%$ & Lebih & $\%$ & Obesitas & $\%$ & & \\
\hline Kelebihan & 0 & 0 & 0 & 0 & 0 & 0 & 0 & 0 & 0 & 0 \\
\hline Cukup & 0 & 0 & 0 & 0 & 0 & 0 & 1 & 100 & 1 & 100 \\
\hline $\begin{array}{l}\text { Defisiensi } \\
\text { ringan }\end{array}$ & 1 & 50 & 0 & 0 & 1 & 50 & 0 & 0 & 2 & 100 \\
\hline $\begin{array}{l}\text { Defisiensi } \\
\text { sedang }\end{array}$ & 3 & 50 & 0 & 0 & 1 & 16.7 & 2 & 33.3 & 6 & 100 \\
\hline $\begin{array}{l}\text { Defisiensi } \\
\text { berat }\end{array}$ & 31 & 72.1 & 1 & 2.3 & 7 & 16.3 & 4 & 9.3 & 43 & 100 \\
\hline
\end{tabular}

Dari tabel 4 menuunjukan bahwa sbagian besar respnden yang memiliki asupan energi cukup berstatus gizi obesitas (100\%), sedangkan responden yang defisit ringan (50\%), sedang (50\%) dan berat (72.1\%) asupan energy berstatus gizi baik.

Tabel 5. Hubungan Asupan Energi dengan Status Gizi

\begin{tabular}{lccccc}
\hline \multicolumn{1}{c}{ Variabel } & Min & Max & Mean & SD & $\mathbf{p}^{*}$ \\
\hline Asupan energi & 483.57 & 1989.01 & 1198.36 & 357.37 & 0.268 \\
\hline Status Gizi & -3.09 & 2.81 & 0.50 & 1.29 & \\
\hline
\end{tabular}

*) Uji Parson Product Moment

Rata-rata asupan energy responden pada penelitian ini sbesar 1198.36 kkal yang termasuk dalam kategori defisit berat, sedangkan rata-rata status gizi responden pada pnelitian ini sebesar 0.50 yang termsuk dalam kategori baik. Hasil tabel 5 menunjukan bahwa tidak ada hubungan antara asupan energi dengan status gizi.

Hasil ini didukung oleh penelitian yang menatakan bahwa tidk terdapat hubungan yang bermkna ( $p>0,05)$ antara asupan energi dengan status gizi remaja di Madasah Aliyah Anajah Petukngan, Jakarta Selatan [16]. Penelitian lainnya menyebutkan bahwa tidak adnya hubungan anara asupan enrgi dengan stattus gizi dapat disebabkan oleh karena konsumsi pangan yang tidak mencerminkan dari keseluruhan gmbaran status gizi pada saat ini, sebab sttus gizi merupakan efek dari apa yang konsumsi sebelumnya dan penyakit infksi yang dideritanya [17].

Hubungan Asupan Protein dengan Status Gizi

Asupan protein diperoleh dari asupan makan sehari ditambah dengan jajanan di kantin sekolah maupun di luar sekolah. Berikut merupakan distribusi asupan protein dengan status gizi pada remaja putri :

JIGK Vol. 3, No. 01, Agustus 2021: $01-08$ 
Tabel 6. Distribusi Asupan Protein dengan Status Gizi

\begin{tabular}{|c|c|c|c|c|c|c|c|c|c|c|}
\hline \multirow[b]{2}{*}{$\begin{array}{l}\text { Asupan } \\
\text { Protein }\end{array}$} & \multicolumn{8}{|c|}{ Status Gizi } & \multirow[b]{2}{*}{ Jumlah } & \multirow[b]{2}{*}{$\%$} \\
\hline & Baik & $\%$ & Kurang & $\%$ & Lebih & $\%$ & Obesitas & $\%$ & & \\
\hline Kelebihan & 0 & 0 & 0 & 0 & 0 & 0 & 0 & 0 & 0 & 0 \\
\hline Cukup & 2 & 50 & 0 & 0 & 1 & 25 & 1 & 25 & 4 & 100 \\
\hline $\begin{array}{l}\text { Defisiensi } \\
\text { ringan }\end{array}$ & 1 & 50 & 0 & 0 & 1 & 50 & 0 & 0 & 2 & 100 \\
\hline $\begin{array}{l}\text { Defisiensi } \\
\text { sedang }\end{array}$ & 2 & 100 & 0 & 0 & 0 & 0 & 0 & 0 & 2 & 100 \\
\hline $\begin{array}{l}\text { Defisiensi } \\
\text { berat }\end{array}$ & 30 & 68.2 & 1 & 2.3 & 7 & 15.9 & 6 & 13.6 & 44 & 100 \\
\hline
\end{tabular}

Dari tabel 6. Menunjukan bahwa sebagan besar responden yang memliki asupan protein cukup (50\%), defisit ringan(50\%), sedang $(50 \%)$ dan berat $(72.1 \%)$ memiliki status gizi baik. Defisiensi protein akan menyebabkan masalah pada asupaan dan sistem transprtasi zat-zat gizi, jika berlebih, protin akan mengalami deaminasi, yaitu nitrogen akan dikeluarkan dari tubuh dan sia-sisa ikatan karbon akan diubah menjdi lemak didalam tubuh. Kecukupan asupan protein akan terpnuhi apabila kecukupan asupan energy juga telah terpenuhi, hal ini terjadi karena protein akan dibaakar menadi panas dan tenga apabila cadangan dari energi masih berada di bawah kebutuhan [18].

Tabel 7. Hubungan Asupan Protein dengan Status Gizi

\begin{tabular}{lccccc}
\hline \multicolumn{1}{c}{ Variabel } & Min & Max & Mean & SD & p $^{*}$ \\
\hline Asupan protein & 17.20 & 69.12 & 38.30 & 10.92 & 0.381 \\
Status Gizi & -3.09 & 2.81 & 0.50 & 1.29 & \\
\hline
\end{tabular}

*) Uji Pearson Produuct Moment

Rata-rata asupan protein responden pada penelitian ini sebesar $38.30 \mathrm{~g}$ yang termasuk dalam kategori defisit berat, sedangkan rata-rata stattus gizi responden pada peenelitian ini sebesar 0.50 yang termasuk dalam kategori baik. Hasil tabel 7 menunjukan bahwa tidak adanya hubungan antra asupan protein dengan staus gizi. Hal ini dapat disebabkan sebagian besar responden memiliki asupan protein dengan kategori defisiensi berat berstatus gizi baik.

Penelitian pada remaa umur 13-15 tahun di Provinsi DKI Jakarta menyatakan bahwa tidak ada hubungan yang signifikan antara asupan protein dengan status gizi pada remaja umu 13-15 tahun di Provinsi DKI Jakarta dengan nilai hasil uji korelasi $\mathrm{p}=0,32$ [19]. Penelitian lain menyatakan tidak ada hubungan antra asupan protein dengn status gizi, hal tersebut dapat dikarenakan responden yang memiliki asupan protein kategori defisit tetapi berstatus gizi gemuk dapat disebabkan karena kebutuhan energy responden tercukupi dari karbohidrat dan lemak [20].

Asupan protein yang kurang bersamaan dengan kekurangan energi yang berkepanjangan dapat menyebabkan kekurangan gizi. Faktor risiko terjadinya gizi kurang dapat disebabkan karena rendahnya konsumsi makanan sumber protein. Konsumsi makanan yang kurang memenuhi kebutuhan merupakan salah satu faktor yang mempengaruhi pertumbuhan dan status gizi [12]. Konsumsi protein yang berlebih bersamaan dengan sumber energi yang berlebih dapat meningkatkan status gizi, dan sebaliknya.

\section{Hubungan Asupan Lemak dengan Status Gizi}

Asupan lemak diperoleh dari asupan makan sehari ditambah dengan jajanan di kantin sekolah maupun di luar sekolah. Berikut merupakan distribusi asupan lemak dengan status gizi pada remaja putri :

JIGK Vol. 3, No. 01, Agustus 2021: 01 - 08 
Tabel 8. Distribusi Asupan Lemak dengan Status Gizi

\begin{tabular}{|c|c|c|c|c|c|c|c|c|c|c|}
\hline \multirow{2}{*}{$\begin{array}{l}\text { Asupan } \\
\text { Lemak }\end{array}$} & \multicolumn{8}{|c|}{ Status Gizi } & \multirow[b]{2}{*}{ Jumlah } & \multirow[b]{2}{*}{$\%$} \\
\hline & Baik & $\%$ & Kurang & $\%$ & Lebih & $\%$ & Obesitas & $\%$ & & \\
\hline Kelebihan & 3 & 60 & 0 & 0 & 0 & 0 & 2 & 40 & 5 & 100 \\
\hline Cukup & 3 & 27.3 & 1 & 9.1 & 3 & 27.3 & 4 & 36.4 & 11 & 100 \\
\hline $\begin{array}{l}\text { Defisiensi } \\
\text { ringan }\end{array}$ & 3 & 100 & 0 & 0 & 0 & 0 & 0 & 0 & 3 & 100 \\
\hline $\begin{array}{l}\text { Defisiensi } \\
\text { sedang }\end{array}$ & 4 & 66.7 & 0 & 0 & 2 & 33.3 & 0 & 0 & 6 & 100 \\
\hline $\begin{array}{l}\text { Defisiensi } \\
\text { berat }\end{array}$ & 22 & 81.5 & 0 & 0 & 4 & 14.8 & 1 & 3.7 & 27 & 100 \\
\hline
\end{tabular}

Dari tabel 8 menunjukkkan bahwa sebagian besar responden yang memiliki asupan lemak cukup berstatus gizi obesitas (36.4\%), dan sebagian besar responden yang memiliki asupan lemak defisit ringan (100\%), sedang $(66.7 \%)$, berat $(81,5 \%)$ dan kategori kelebihan $(60 \%)$ berstatus gizi baik. Lemak merupakan salh satu zat gizi yng menghasilkan energi dalam jumlah besar [21]. Konsumsi lemak yang melebih dari kebutuhan tubuh dapat menyebabkan penibunan lemak dlam jaringan adiposa yang akhirnya akan menjadi kegemukan [22].

Tabel 9. Hubungan Asupan Lemak dengan Status Gizi

\begin{tabular}{lccccc}
\hline \multicolumn{1}{c}{ Variabel } & Min & Max & Mean & SD & p* \\
\hline Asupan lemak & 19.81 & 111.29 & 54.06 & 19.11 & 0.033 \\
Status Gizi & -3.09 & 2.81 & 0.50 & 1.29 & \\
\hline
\end{tabular}

*) Uji Pearson Product Momnt

Analisis uji hubungan asupan lemak dengan status gizi dapat dilihat pada tabel 9. Hasil tabel 9 menunjukan bahwa ada hubungan antara asupan lemak dengan status gizi. Rata-rata asupan lemak responden pada penelitian ini sebesar $54.06 \mathrm{~g}$ yang termasuk dalam kategori defisit sedang, sedangkan rata-rata status gizi responden pada penelitian ini sebesar 0.50 yang termasuk dalam kategori baik.

Penelitian di Fakultas Ilmu Kesehatan UMS menyatakan bahwa ada hubungan signifikan antara asupan lemak dengan status gizi $(\mathrm{p}=0,000)$ pada remaja yang oveweight dengan remaja yang mempuyai status gizi normal. Konsumsi makanan yang berlebihan membuat energi yang diterima oleh tubuh menjadi lebih tinggi dan dapat menjadi faktor utama penyebab overweight [23]. Asupan lemak dapat mempengaruhi status gizi seseorang. Lemak menjadi salah satu penyumbang cadangan makanan terbanyak, sehingga dapat menyebabkan overweight dan obesitas. Sehingga apabila asupan lemak yang kurang pada seseorang dapat menimbulkan pengurangan ketersediaan energi dan menyebabkan status gizi menjadi lebih stabil [24].

Hubungan Asupan Karbohidrat dengan Status Gizi

Asupan karbohidrat diperoleh dari asupan makan sehari ditambah dengan jajanan di kantin sekolah maupun di luar sekolah.

Tabel 10. Asupan Karbohidrat dengan Status Gizi

\begin{tabular}{|c|c|c|c|c|c|c|c|c|c|c|}
\hline \multirow{2}{*}{$\begin{array}{c}\text { Asupan } \\
\text { Karbohidrat }\end{array}$} & \multicolumn{8}{|c|}{ Status Gizi } & \multirow{2}{*}{ Jumlah } & \multirow{2}{*}{$\%$} \\
\hline & Baik & $\%$ & Kurang & $\%$ & Lebih & $\%$ & Obesitas & $\%$ & & \\
\hline Kelebihan & 0 & 0 & 0 & 0 & 0 & 0 & 0 & 0 & 0 & 0 \\
\hline Cukup & 0 & 0 & 0 & 0 & 0 & 0 & 0 & 0 & 0 & 0 \\
\hline $\begin{array}{l}\text { Defisiensi } \\
\text { ringan }\end{array}$ & 0 & 0 & 0 & 0 & 0 & 0 & 0 & 0 & 0 & 0 \\
\hline $\begin{array}{l}\text { Defisiensi } \\
\text { sedang }\end{array}$ & 2 & 66.7 & 0 & 0 & 0 & 0 & 1 & 33.3 & 3 & 100 \\
\hline $\begin{array}{l}\text { Defisiensi } \\
\text { berat }\end{array}$ & 33 & 67.3 & 1 & 2 & 9 & 18.4 & 6 & 12.2 & 49 & 100 \\
\hline
\end{tabular}

JIGK Vol. 3, No. 01, Agustus 2021: $01-08$ 
Dari tabel 10 menunjukkan bahwa sebagian besar responden yang defisit sedang (66.7\%) dan berat (67.3\%) berstatus gizi baik. Karbohidrat sebagai sumber energi utama untuk beberapa sel. Didalam otot, juga membutuhkan karbohidrat untuk melakukan aktivitas fisik. Cadangan karbohidrat tersedia dalam bentuk glukosa darah serta disimpan dalam bentuk glikogendi dalam hati dan otot [25].

\section{Tabel 11. Hubungan Asupan Karbohidrat dengan Status Gizi}

\begin{tabular}{lccccc}
\hline \multicolumn{1}{c}{ Variabel } & Min & Max & Mean & SD & $\mathbf{p}^{*}$ \\
\hline Asupan karbohidrat & 43.97 & 254.96 & 139.52 & 46 & 0.841 \\
Status Gizi & -3.09 & 2.81 & 0.50 & 1.29 & \\
\hline
\end{tabular}

*) Uji Pearson Product Moment

Rata-rata asupan karbohidrat responden pada penelitian sebesar $139.52 \mathrm{~g}$ yang termasuk dalam kategori defisit berat, sedangkan rata-rata status gzi responden pda penelitian ini sebesar 0.50 yang termasuk dalam kategori baik. Hasil tabel 11 menunjukan bahwa tidak ada hubungan antara asupan karbohidrat dengan status gizi. Tidak terdapatnya hubungan ini dapat dikarenakan rata-rata jumlah asupan karbohidrat yang dikonsumsi responden dalam kategori defisit berat akan tetapi sebagian besar responden memiliki status gizi baik.

Penelitian yang dilkukan oleh Rinanti menyatakan baha tidak ada hubungan anara asupan karbohidrat dengan status gizi pada remaja $(p=0,216)$, hal ini karena jenis makanan sumber karbohidrat yang dikonsumsi responden kurang bervariasi dan jumlahnya yang sedikit [26]. Penelitian lain yang dilakukan di SMA Muhammadiyah 4 Surakarta yang menyatakan tidak ada hubungan antar asupn karbohidrat dengan status gizi denan nilai $\mathrm{p}=0,230$, hal tersebut dikarenakan rata-rata asupan karbohidrat sebesar $246 \mathrm{gram} /$ hari dalam kategori defisit sedang (72\% dari $\mathrm{AKG})[27]$.

\section{KESIMPULAN}

Asupan enegi, protein, leak dan karbhidrat rata-rata termasuk dalam kategori defisiensi berat, status gizi sebagian besar termasuk gizi baik. Terdapat hubungan asupan lemak dengan stats gii, tidak terdapat hubungan asupan energi, protein, karbohidrat dengan status gizi.

\section{SARAN}

Ketidakseimbangan antara asupan energi, lemak, protein dan karbohidrat dengan kebutuhan gizi akan mempengaruhi status gizi remaja. Edukasi serta pemeriksaan antropometri secara berkelanjutan sangat penting dilakukan. Hal ini penting guna membiasakan remaja putri mengontrol asupan serta status gizinya.

\section{DAFTAR PUSTAKA}

[1]. Deshmukh, V.R., Kulkarni, A.A. Body image and its relation with body mass index among Indian Adolescent. Indian Pediatrics. 54 (12) : 1025-1028. doi: 10.1007/s13312-017-12050. (2017).

[2]. Brown JE. Nutrition Through the Life Cycle.Wadsworth, USA. (2013).

[3]. Cunningham, K., Ruel, M., Ferguson, E., dan Uauy, R. Women's Empowerment and Child Nutritional Status in South Asia: a Synthesis of The Literature. Maternal Child Nutrition.11(1): 1-19. doi: 10.1111/mcn.12125. (2015).

[4]. Mardalena I. Dasar-Dasar Ilmu Gizi dalam Keperawatan. Yogyakarta : Pustaka Baru Press. (2017).

[5]. UNICEF. Penuntun Hidup Sehat. Jakarta : Pusat Promosi Kesehatan Kementerian Kesehatan RI. (2010).

[6]. Riset Kesehatan Dasar (RISKESDAS). Laporan Nasional Riskesdas. Badan Penelitian Dan Pengembangan Kesehatan. Kementerian Kesehatan RI. (2013).

[7]. Riset Kesehatan Dasar (RISKESDAS). Laporan Nasional Riskesdas. Badan Penelitian Dan Pengembangan Kesehatan. Kementerian Kesehatan RI. (2018). 
[8]. Riset Kesehatan Dasar (RISKESDAS). (2018). Laporan Provinsi Bali Riskesdas Badan Penelitian Dan Pengembangan Kesehatan Kementerian Kesehatan RI.

[9]. Rachmayani, A.S., Kuswari M., Melani V. Hubungan Asupan Zat Gizi dan Status Gizi Remaja Putri di SMK Ciawi Bogor. Indonesian Journal of Human Nutrition. Vol 5: 2. doi: http://dx.doi.org/10.21776/ub.ijhn.2018.005.02.6. (2018).

[10].Rokhmah, F., Muniroh, L., Nindya, S.T. Hubungan Tingkat Kecukupan Energi dan Zat Gizi Makro dengan Status Gizi Siswi SMA di Pondok Pesantren Al-Izzah Kota Batu. Media Gizi Indonesia. Vol. 11 (1) : 94-100. doi : http://dx.doi.org/10.20473/mgi.v11i1.94-100. (2016).

[11].Kusmiran, E. Kesehatan Reproduksi Remaja dan Wanita. Jakarta : Salemba Medika. (2016).

[12].Hardinsyah., Supariasa N.D.I. Ilmu Gizi Teori dan Aplikasi. Jakarta. ECG. (2016).

[13].Departemen Kesehatan Republik Indonesia. Pedoman Umum Gizi Seimbang, Jakarta: Direktorat Bina Gizi Masyarakat. (2003).

[14].Kemenkes. Peraturan Menteri Kesehatan Republik Indonesia Nomor 2 Tahun 2020 : Standar Antropometri Anak. Jakarta : Direktorat Bina Gizi. (2020).

[15].Aulia, N. R. . (2021). Peran Pengetahuan Gizi Terhadap Asupan Energi, Status Gizi Dan Sikap Tentang Gizi Remaja. Jurnal Ilmiah Gizi Dan Kesehatan (JIGK), 2(02), 31-35. https://doi.org/10.46772/jigk.v2i02.454

[16].Mustika, MA. Tingkat aktivitas fisik, tingkat konsumsi zat gizi, dan status gizi siswa di Pondok Pesantren Al Falak Kota Bogor. Skripsi. Bogor: Institut Pertanian Bogor. (2012).

[17].Nurwulan, E., Furqan, M. Relationship between nutrition intake, eat patterns, and nutrition knowledge with nutritional status of santri in At-Thayyibah Orphan Boarding School Sukabumi, ARGIPA (Arsip Gizi dan Pangan) 2(2):65-74. DOI:10.22236/argipa.v2i2. (2020).

[18].Almatsier, S. Prinsip Dasar Ilmu Gizi. Jakarta : PT. Gramedia. Pustaka Utama. (2011).

[19].Sasmito, D.P. Hubungan Asupan Zat Gizi Makro (Karbohidrat, Protein, Lemak) dengan Kejadian Obesitas pada Remaja Umur 13- 15 tahun di Propinsi DKI Jakarta (Analisis Data Sekunder Riskesdas 2010). Nutrire Diaita. Volume 7 nomor 1. (2015).

[20].Siwi, N.P., Paskarini, I. Hubungan Asupan Karbohidrat, Protein, Lemak dengan Status Gizi. The Indonesian Journal Of Public Health ;13(1). (2018)

[21].Sediaoetama, D.A. Ilmu Gizi. Jakarta : Dian Rakyat. (2010).

[22].Beck, M. Ilmu Gizi dan Diet Hubungannya dengan Penyakit-Penyakit untuk Perawat dan Dokter. Yogyakarta. Yayasan Essentia Medica. (2011).

[23].Rahmawati, D.D. Perbedaan Persen Lemak Tubuh, Konsumsi Lemak, Karbohidrat dan Air pada Remaja Putri Overweight dan Non Overweigt di Fakultas Ilmu Kesehatan. Universitas Muhammadiyah Surakarta, 1- 17. (2015).

[24].Kartasapoetra, M. Ilmu Gizi (Korelasi Gizi, Kesehatan dan Produktivitas Kerja). Rineka Cipta. Jakarta. (2010).

[25].Barasi, M. E. At a Glance: Ilmu Gizi. Jakarta. PT Gramedia Pustaka Utama. (2011).

[26].Rinanti, O.S. Hubungan Asupan Zat Gizi Makro dan Pengetahuan Gizi Seimbang Dengan Status Gizi Siswa-Siswi di SMP Muhammadiyah 1 Kartasura. Fakultas Ilmu Kesehatan, Universitas Surakarta. Surakarta (2014).

[27].Wulandari, T.D., Mardiyati, L.N. Hubungan Antara Asupan Karbohidrat dan Lemak dengan Kejadian Overweight pada Remaja di SMA Muhammadiyah 4 Kartasura Kabupaten Sukoharjo. Jurnal Riset Kesehatan. Vol 9 No 1. (2017). 